\title{
Study on Improvement of Dumping Site Stability in Weak Geological Condition by Using Compacted Layer
}

\author{
Takashi Sasaoka, Tri Karian, Tsedendorj Amarsaikhan, Akihiro Hamanaka, \\ Hideki Shimada, Kikuo Matsui \\ Department of Earth Resources Engineering, Kyushu University, Fukuoka, Japan \\ Email: sasaoka@mine.kyushu-u.ac.jp
}

Received 20 February 2015; accepted 16 March 2015; published 23 March 2015

Copyright (C) 2015 by authors and Scientific Research Publishing Inc.

This work is licensed under the Creative Commons Attribution International License (CC BY).

http://creativecommons.org/licenses/by/4.0/

(c) (i) Open Access

\section{Abstract}

Berau Basin, a sub-basin of Tarakan Basin, had been developed during Eocene to Miocene period. Rocks in Berau Basin consist of sedimentary, volcanic and igneous rocks aged from Pre-tertiary until Quaternary epoch. The youngest identified rock formation was alluvial deposit consists of mud, silt, sand, gravel and swamp with brown to dark color. This youngest rock formation is relatively weak geological condition and can cause problems in the coal mining operation. PT Berau Coal as one of the coal mining companies in Berau Basin area had experienced some problems related to the occurrence of alluvial deposit. A large failure has occurred at one of its out pit dumping area which lies over the swamp material. The failure caused a higher operating cost since it made that the distance for waste rock dumping became to be farther than the designated area. Therefore, in order to prevent similar failure occurring at dumping area which lies above swamp material, an improvement of dumping site stability on weak geological condition has to be needed. The proposed method for improving the stability of out pit dumping area in weak geological condition is to construct the compacted layer of waste rock before the out pit dumping area construction. Based on experimental results, a minimum of $40 \mathrm{kPa}$ pressure is needed to give a proper compaction to the waste rock. The result of numerical analysis by Finite Element Method (FEM) shows that construction of compacted layer on the base of out pit dumping area can improve its stability.

\section{Keywords}

Swamp Material, Coal Mining, Out Pit Dump, Waste Rock, Compacted Layer

\section{Introduction}

PT Berau Coal is one of the Indonesian coal mining companies located in Berau Regency, East Kalimantan

How to cite this paper: Sasaoka, T., Karian, T., Amarsaikhan, T., Hamanaka, A., Shimada, H. and Matsui, K. (2015) Study on Improvement of Dumping Site Stability in Weak Geological Condition by Using Compacted Layer. Open Journal of Geology, 5, 144-155. http://dx.doi.org/10.4236/ojg.2015.53014 
Province, Indonesia. PT Berau Coal runs several mining operations within this area. One of its mining operations is located in Lati area (Figure 1(a)). The coal deposit in Lati area is a syncline with Northwest-Southeast axis. The dip of coal seam is around $10^{\circ}$ to $23^{\circ}$. Lati coals consist of 4 major coal seams which are $\mathrm{P}, \mathrm{Q}, \mathrm{R}$ and T seam. The average thicknesses of these seams are $2.6 \mathrm{~m}, 2.4 \mathrm{~m}, 3.1 \mathrm{~m}$ and $2.4 \mathrm{~m}$ respectively. Due to the geometry of coal deposit, the mining activity in Lati area was divided into 5 pits which are Pit West, East, T, Others and North. Boundary of Lati open pit coal mine is shown in Figure 1(b).

Lati area is located in Berau Basin which is a sub-basin of the Tarakan Basin [1]. Formation of the TarakanBasin was begun with transgression process which happened during the Eocene until early Miocene Epoch. In the middle of Miocene, regression in Tarakan Basin occurred continuously by eastward gradational deposition to form delta deposit. Tarakan Basin experienced more active regression during Miocene to Pliocene Epoch. Depocenter thick delta sedimentation process with relatively eastward movement continued as the time goes by. Regionally, rocks in this area consist of sedimentary rock, volcanic rock and igneous rock with predicted age ranging from pre-tertiary to quaternary period. Berau Basin, from the oldest formation to the youngest ones, consist of Banggara Formation (Kbs), Sambakung Formation (Tes), Tabalar Formation (Teot), Birang Formation (Tomb), Latih Formation (Tml), Tabul Formation (Tmt), Labanan Formation (Tmpl), Domaring Formation (Tmpd), Sinjin Formation (Tps), Sajau Formation (TQps) and alluvial deposition (Qa). The stratigraphic column of rocks in Berau area can be seen in Figure 2.

Figure 3 shows regional geology map of Lati area (see Figure 2 for the Index). In general, rocks in this area can be divided into several formations as follows:

a) Birang Formation (Tomb): substitution between napal, limestone and tuff in upper part and substitution between chert, napal, conglomerate, quartz sand and limestone in lower part. Thickness of rock formation is more than $1100 \mathrm{~m}$. Some fossils are contained in the formation which are Lepidocylina ephicides, Spiroclypeus sp., Miogypsina sp., Margionopora vertebralis, Operculina sp., Globigerina tripartita, Globoquadrina altispira, Globorotalia mayeri, Globorotalia peripheronda, Globigerinoides immaturus, Globigerinoides sacculifer, Praeorbulina transitoria, Uvigerina sp., Cassidulina sp. Predicted Epoch: Oligocene-Miocene.

b) Latih Formation (Tml): quartz stone, limestone, siltstone and coal in upper part. Sandy shale in the middle part and limestone at the bottom part. Coal seam with brown, dark color. Thickness of the formation is no more than $800 \mathrm{~m}$. The formation deposited in delta environment estuarine and shallow sea. Some fossils are contained in the formation, such as Praeorbulina glomerosa, Praeorbulina transitioria. Predicted Epoch: early Miocene Middle Miocene.

c) Alluvial deposit (Qa): mud, silt, sand, gravel, pebble and swamps with dark until black color and the thickness is more than 40 meter.

The presence of the youngest rock formation in Lati area, which is alluvial deposit, makes several problems to mining operation especially the waste rock dumping operation due to its weak strength characteristics. In 2007, one of the out pit dumping areas of Pit East was failure (Figure 4). 4,400,000 BCM of overburden in 30 meter height and $40^{\circ}$ slope was collapsed. The base of this dumping area was known to be the swamp material.

Even though the out pit dumping area failure has not caused fatality or equipment damage, it has caused significant financial loss. Waste rock dumping operation plays an important role in mining activities [3]. This operation needs to be conducted effectively in order to reduce the operating cost. Moreover, dumping area must remain stable to ensure a safe and continual mining operation. Waste rock dumping operation in Lati area is planned to be carried out by combination of out pit dumping and backfilling operation. Out pit dumping is needed especially at the beginning of mining activity until there is enough space available of mined out area which can be used for the backfilling operation. The maximum distance of out pit dump is set to be $1.5 \mathrm{~km}$ from the mining front. By this planned operation, the operating cost will be lowered and the disturb area from the mining activity can be minimized. However, the failure resulting higher operating cost since overburden from Pit East has to be dumped further from the designated area. Therefore, in order to prevent the similar case happening at dumping area which lies over swamp material, an improvement for stability of dumping site on weak geological condition is needed. This paper will discuss the impact of swamp material to stability of dumping area which lies above it. Moreover, the improvement of dumping area stability by using compacted layer of waste rock will also be discussed.

\section{Investigation of Failure out Pit Dumping Area}

Site investigation was carried out to find the cause of failure in out pit dump of Pit East. Core and bulk samples 

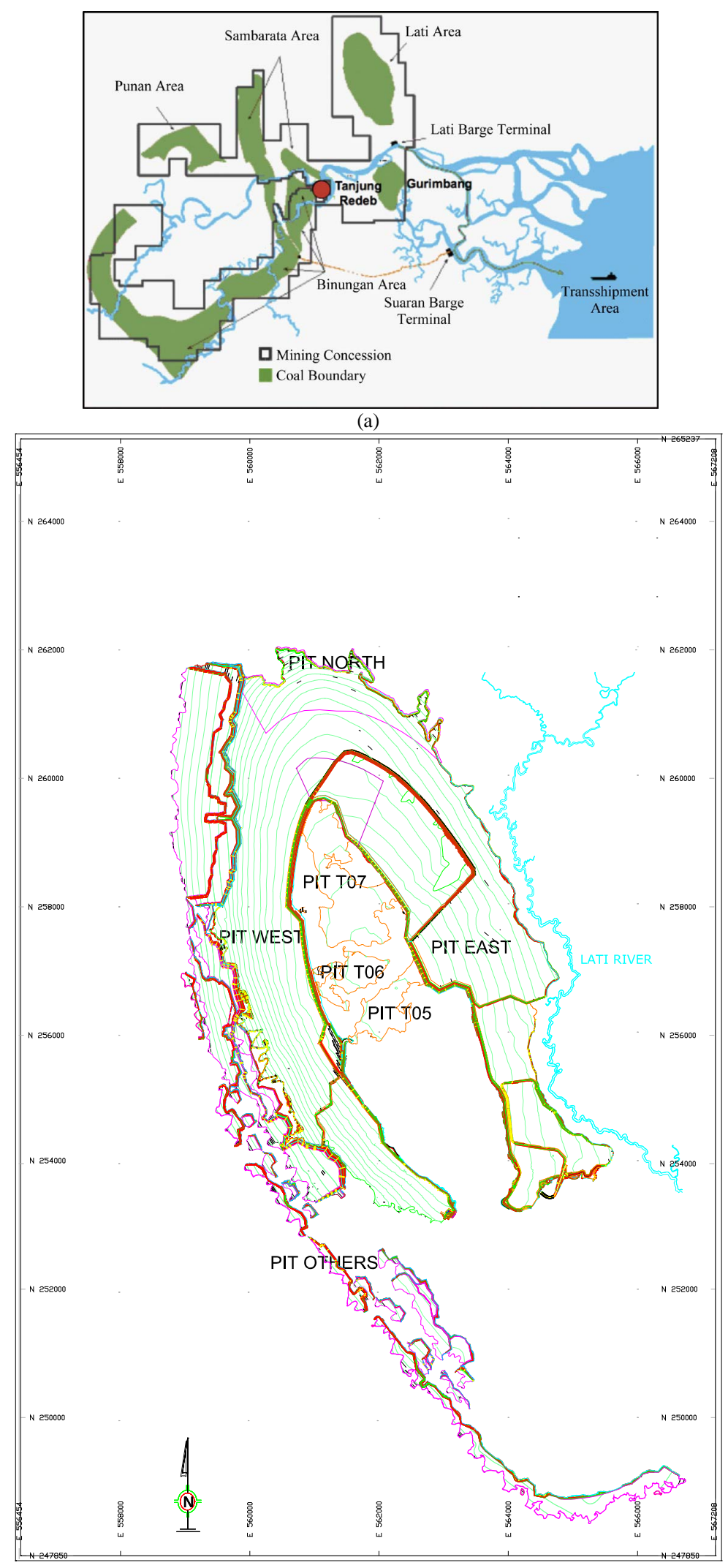

(b)

Figure 1. (a) PT Berau Coal concession area; (b) Lati open pit coal mine boundary. 


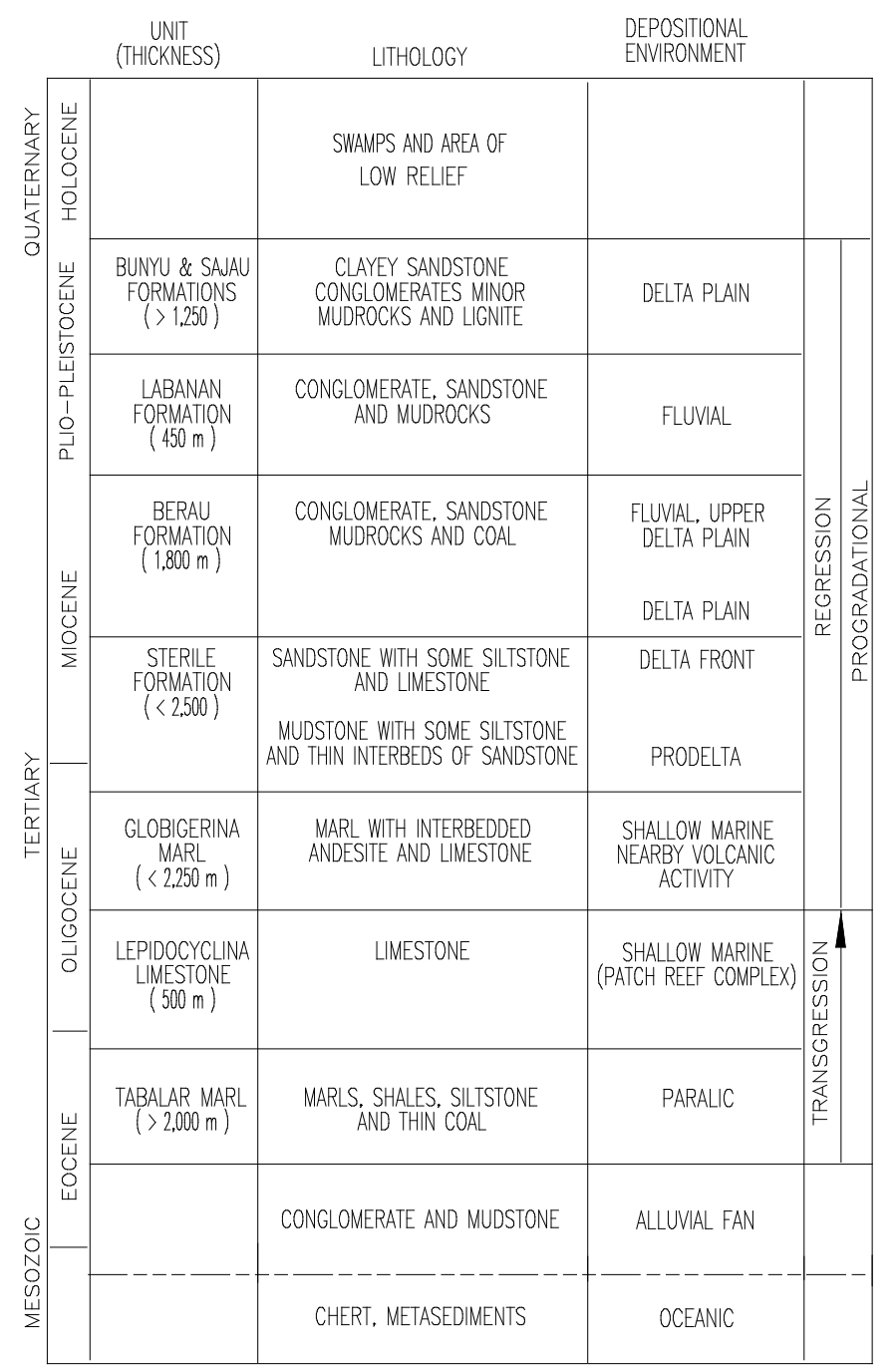

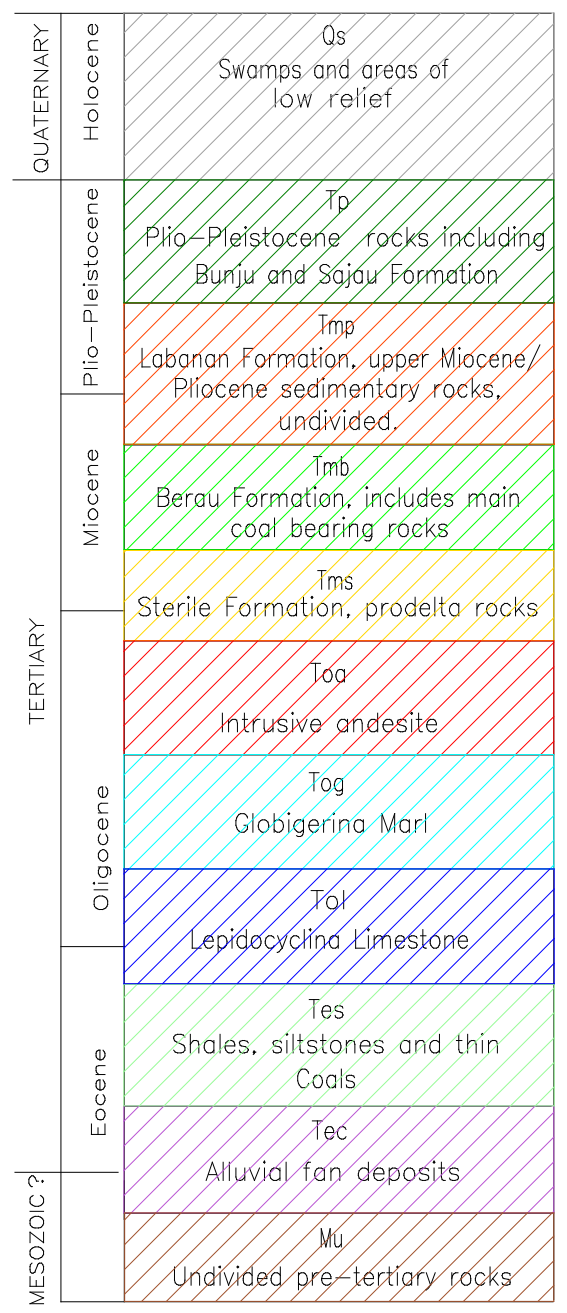

Figure 2. Stratigraphic column of rocks in Berau Area [2].

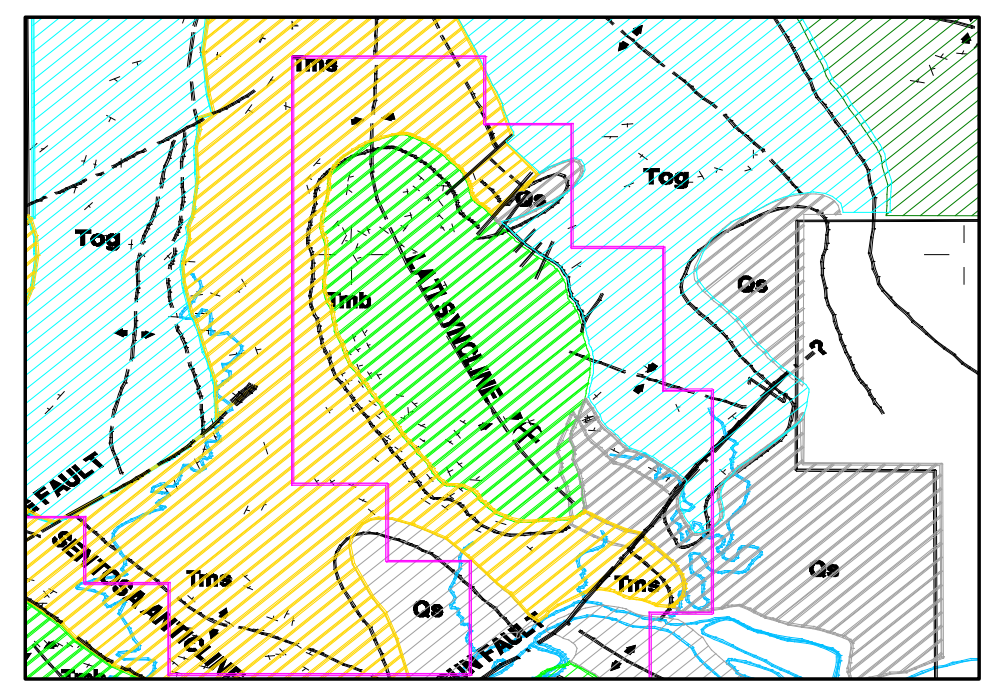

Figure 3. Regional geology map of Lati Area [2]. 


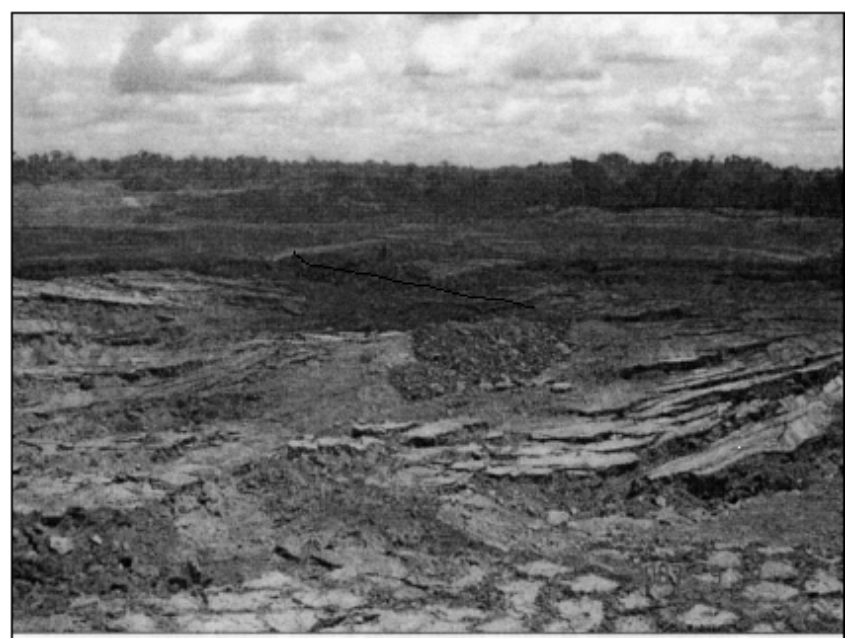

Figure 4. Failure at out pit dumping area near Pit East.

were taken from the failure out pit dump. The samples were then wrapped by series of plastic wrap and aluminum foil to minimize physical and chemical alteration. Finally samples were wrapped by sponge and put into PVC pipe to resist shaking during transportation to the laboratory. Laboratory test was then carried out in order to understand samples' physical and mechanical properties which will be the input data for numerical analysis. Based on the laboratory test, the physical and mechanical properties of waste rock, swamp and base rock materials were given in the Table 1.

Numerical analysis using Finite Element Method (FEM) was carried out to simulate the stability of dumping area by using properties obtained from the laboratory test and geometry of the failure out pit dump. Finite Element Method has been widely known as reliable and accurate method to analyze wide range of slope stability problems such as reported by [4] and [5]. The geometry of numerical model in accordance with the field condition was shown in Figure 5. Simulation was carried out for several dumping stages with height of 10 meter per stage. Figures 6-8 show the numerical analysis result for each dumping stage. Model was considered as failure when strength factor is below 1 or when shear and/or tension failure occurs in the model indicated by cross and circle symbol respectively.

Failure occurs in the model after the third dumping stage as in the real field condition. Each dumping stage height is 10 meter so after the third dumping stage, the total dumping height is 30 meter. Based on the result of numerical analysis, it can be known that the shear failure was occurred at the bottom of the out pit dump from second stage and becoming worse at the third stage. A low strength factor zone at the base of dumping area was increased by increasing height of the out pit dump. Therefore, there is possibility that failure occurring at the base of dumping area triggered the failure of out pit dump by developing crack or slip plane to the surface of dumping area.

The result of numerical analysis shows that the occurrence of swamp material in the base of out pit dumping area has triggered the collapse. To give a better understanding of the influence of swamp material on the stability of the dumping area, further analysis was carried out. A numerical model for an out pit dump with no swamp material underneath was constructed and the result is shown in Figure 9. Moreover, numerical models for an out pit dump with several different thickness of swamp material at the base were also constructed in order to understand the influence of swamp material thickness and the result are shown in Figure 10, Figure 11.

Figure 9 shows that the strength factor of dumping area without existence of swamp material is in stable condition (the strength factor is more than 1). This result is strengthens by no shear or tension failure developed around the base of the out pit dumping area. Figure 10 and Figure 11 represent that the out pit dumping area is becoming more unstable by increasing thickness of the swamp material. Therefore, the existence of swamp material has obvious impact on the stability of dumping area.

\section{Improvement of Stability of Dumping Site}

The previous analysis has shown that the swamp material which is the base of the out pit dumping area is the 
Table 1. Physical and mechanical properties of rocks around out pit dumping area.

\begin{tabular}{ccccc}
\hline Material Properties & Unit & Base Rock & Swamp Material & Waste Rock \\
\hline Density & $\mathrm{MN} / \mathrm{m}^{3}$ & 0.02 & 0.015 & 0.015 \\
Young's modulus & $\mathrm{MPa}$ & 1000 & 50 & 50 \\
Poisson ratio & & 0.4 & 0.4 & 0.4 \\
Shear strength & $\mathrm{MPa}$ & 0.15 & 0.02 & 0.07 \\
Internal friction angle & Degree & 30 & 20 & 25 \\
Cohesion & $\mathrm{MPa}$ & 0.15 & 0.02 & 0.07 \\
\hline
\end{tabular}

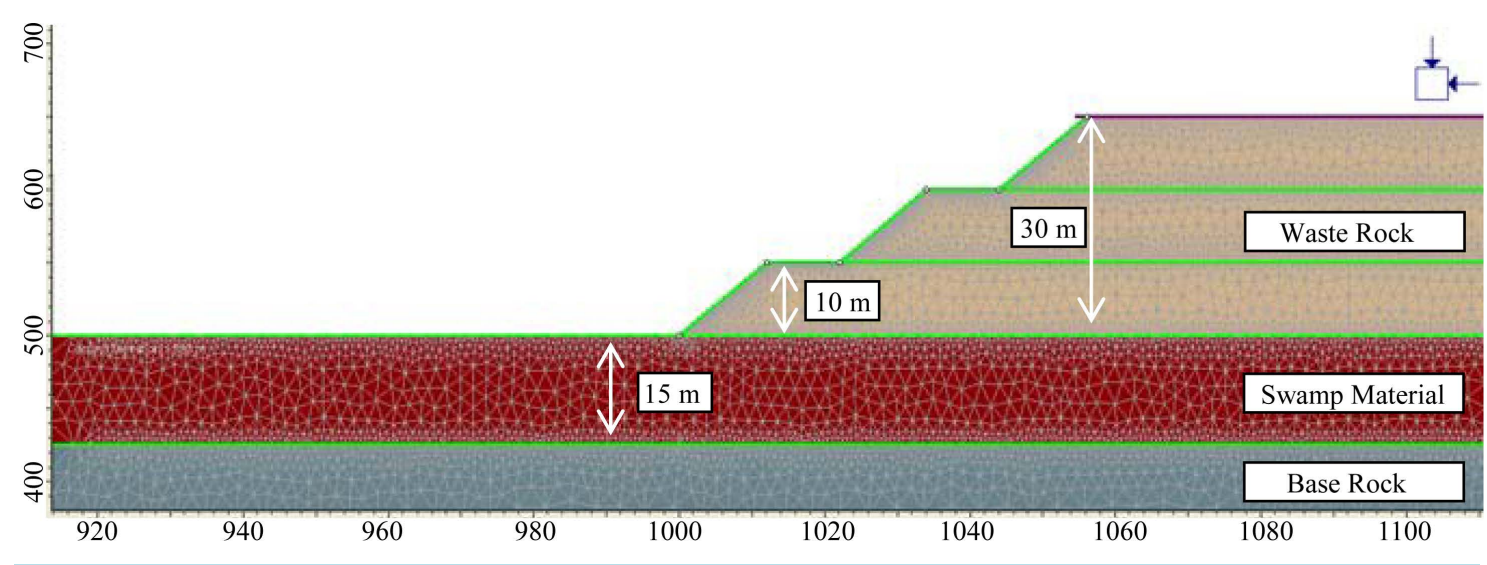

Figure 5. Geometry of numerical model.

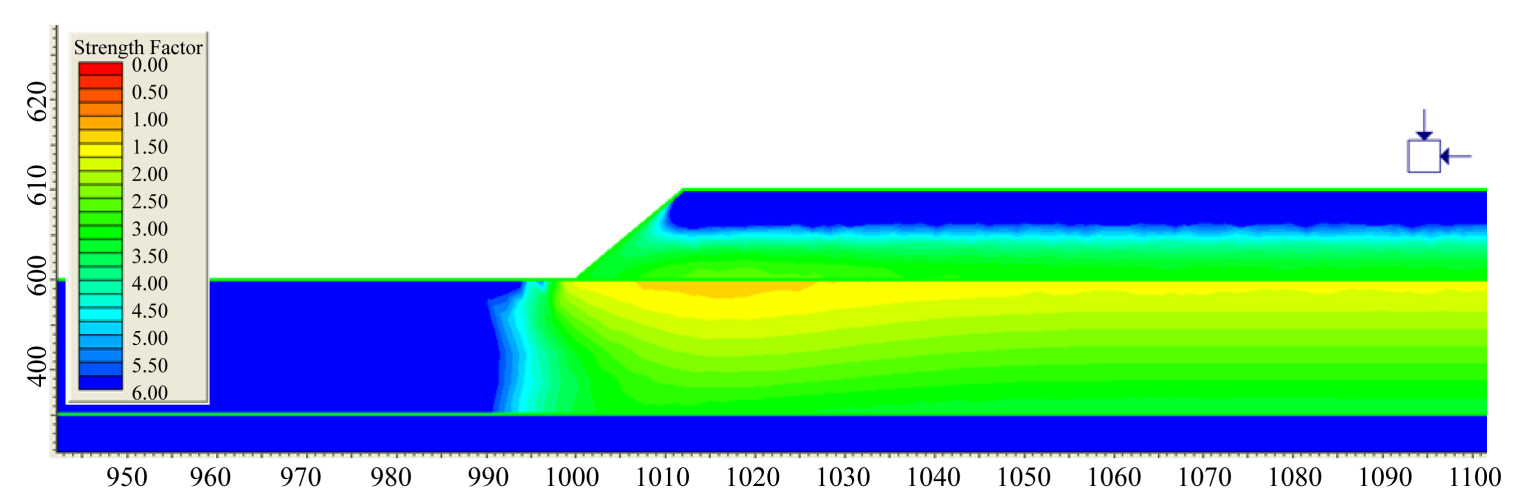

Figure 6. Result of numerical analysis for first dumping stage.

cause of failure. Therefore, an improvement must be taken in order to prevent such failure occurs at other dumping site with similar condition and to prevent additional loss at the operating cost. The proposed method to improve stability of the out pit dumping area is by layering the base of the out pit dumping area with compacted waste rock before the waste rock dump is constructed.

\subsection{Waste Rock Compaction Test}

To understand characteristic of waste rock material when being compacted, three samples were taken from dumping site Q10 located near Pit East. Water content (w) of sample 1, 2, and 3 are 11.0\%, 12.5\% and 14.0\% respectively. Samples were compacted using mold and hammer [6]. The compacted sample can be seen in Figure 12. The coefficient of permeability of each samples was then determined and the result represent in Figure 13.

Based on the result shown in Figure 13, the coefficient of permeability is decrease with increasing compaction 


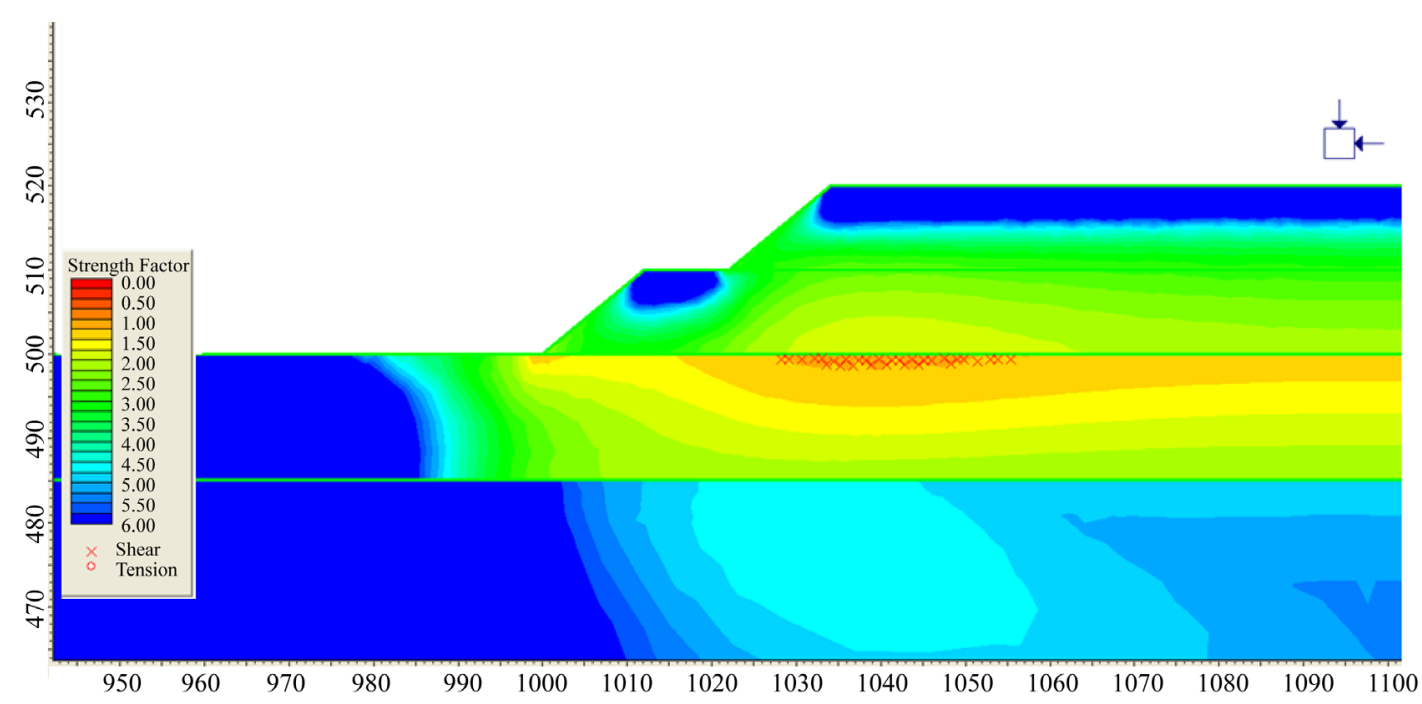

Figure 7. Result of numerical analysis for second dumping stage.

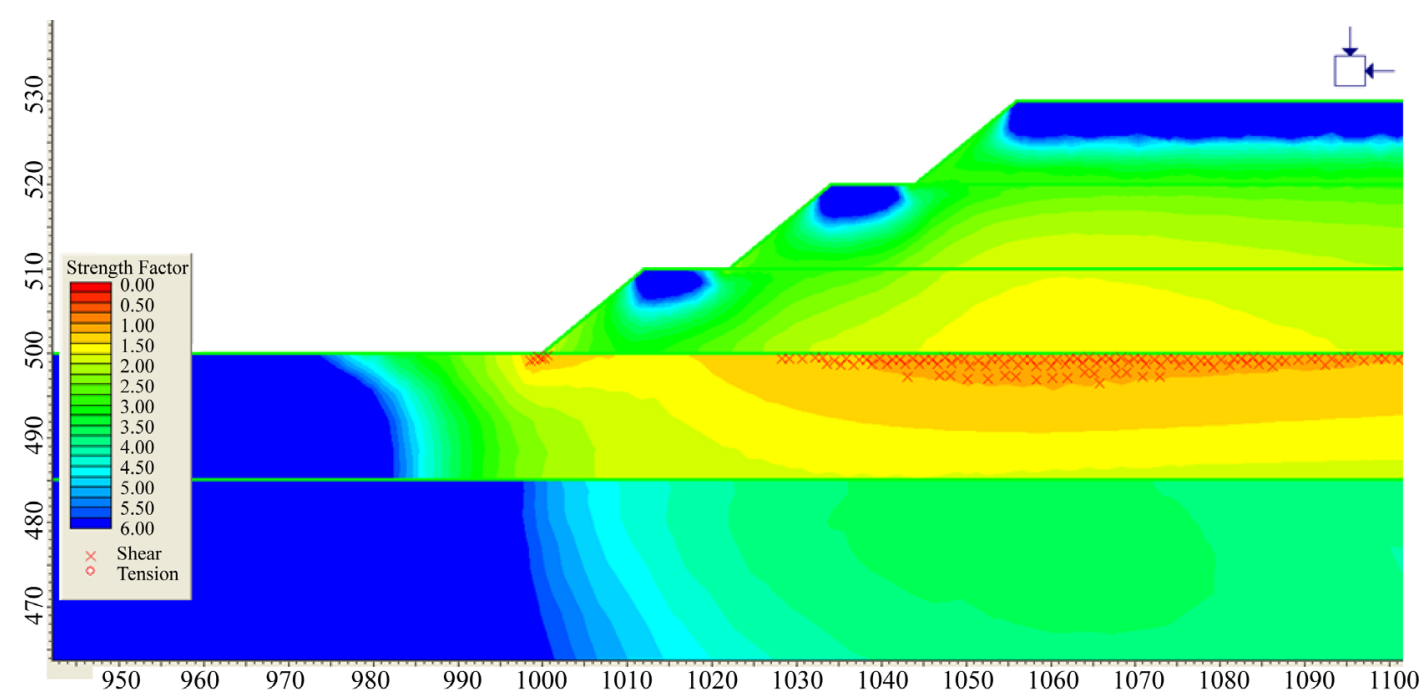

Figure 8. Result of numerical analysis for third dumping stage.

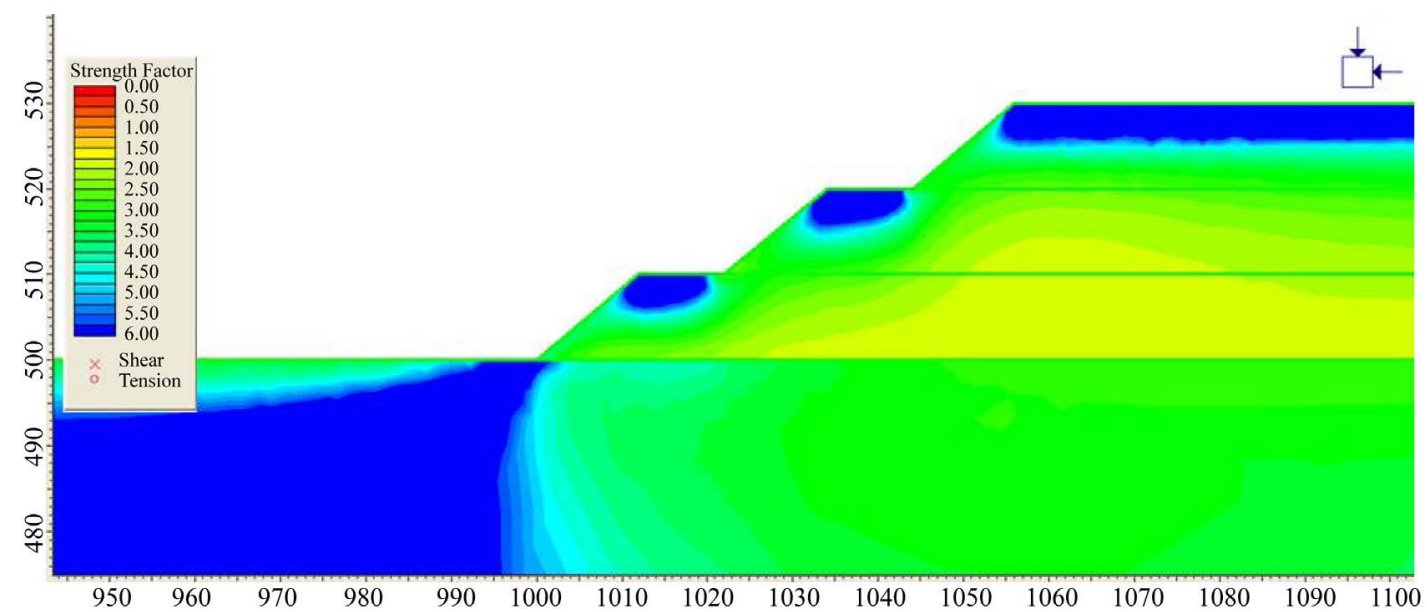

Figure 9. Result of numerical analysis for out pit dumping area without existence of swamp material. 


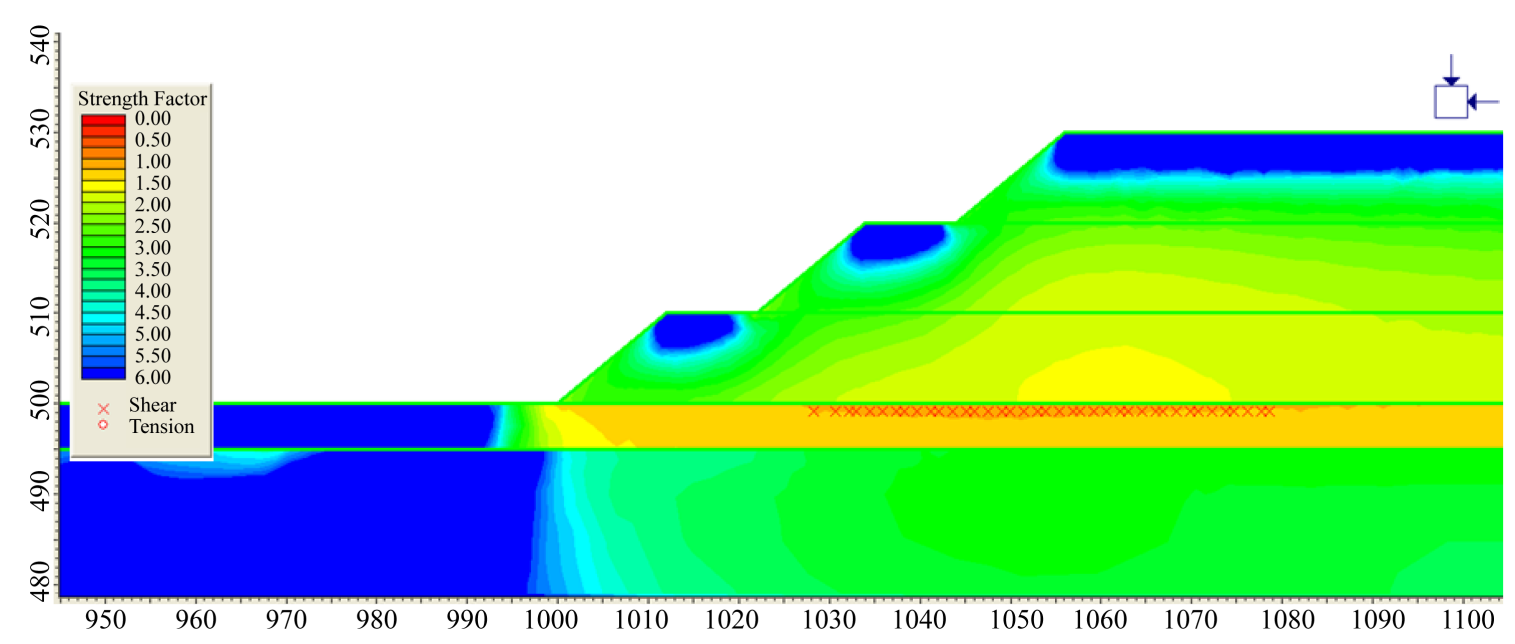

Figure 10. Result of numerical analysis for out pit dumping area with $5 \mathrm{~m}$ thickness of swamp material.

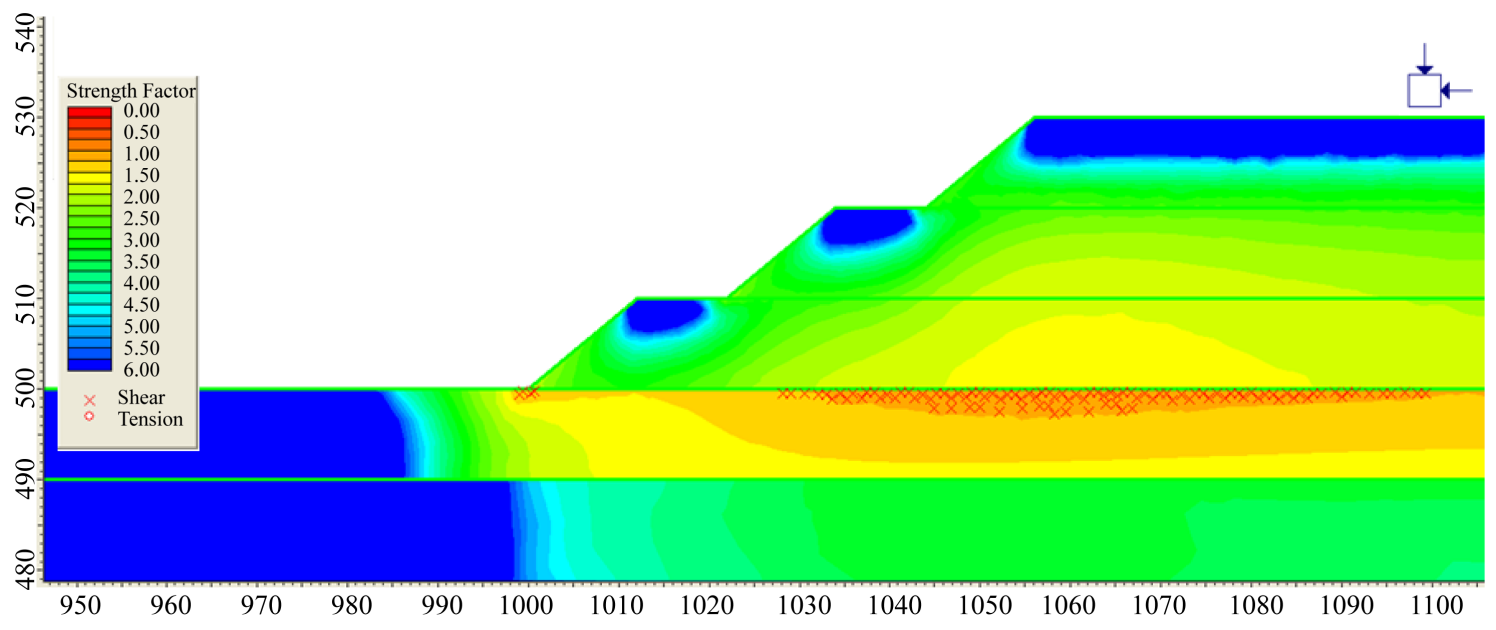

Figure 11. Result of numerical analysis for out pit dumping area with $10 \mathrm{~m}$ thickness of swamp material.

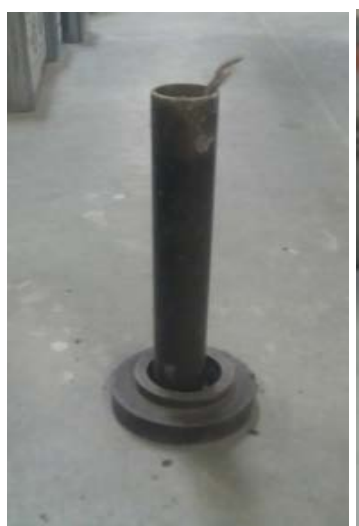

(a)

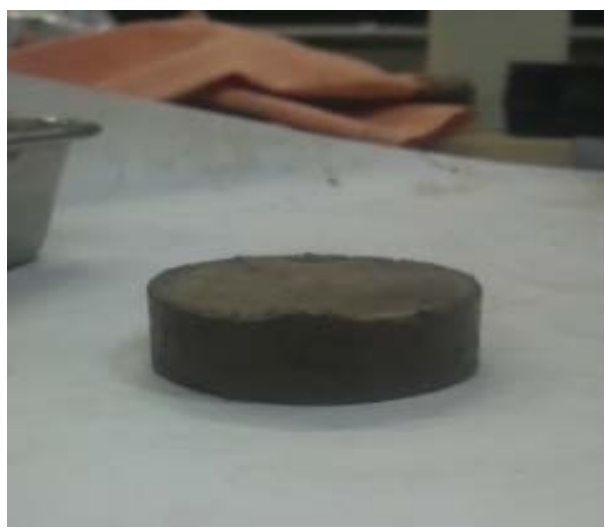

(b)

Figure 12. (a) Mold and hammer for compaction process; (b) Sample after compaction process.

pressure. The coefficient of permeability of samples 2 and 3 are relatively low compared with that of sample 1 . The reason behind this result was the water content of the sample 2 and 3 which is higher than sample 1 . The 


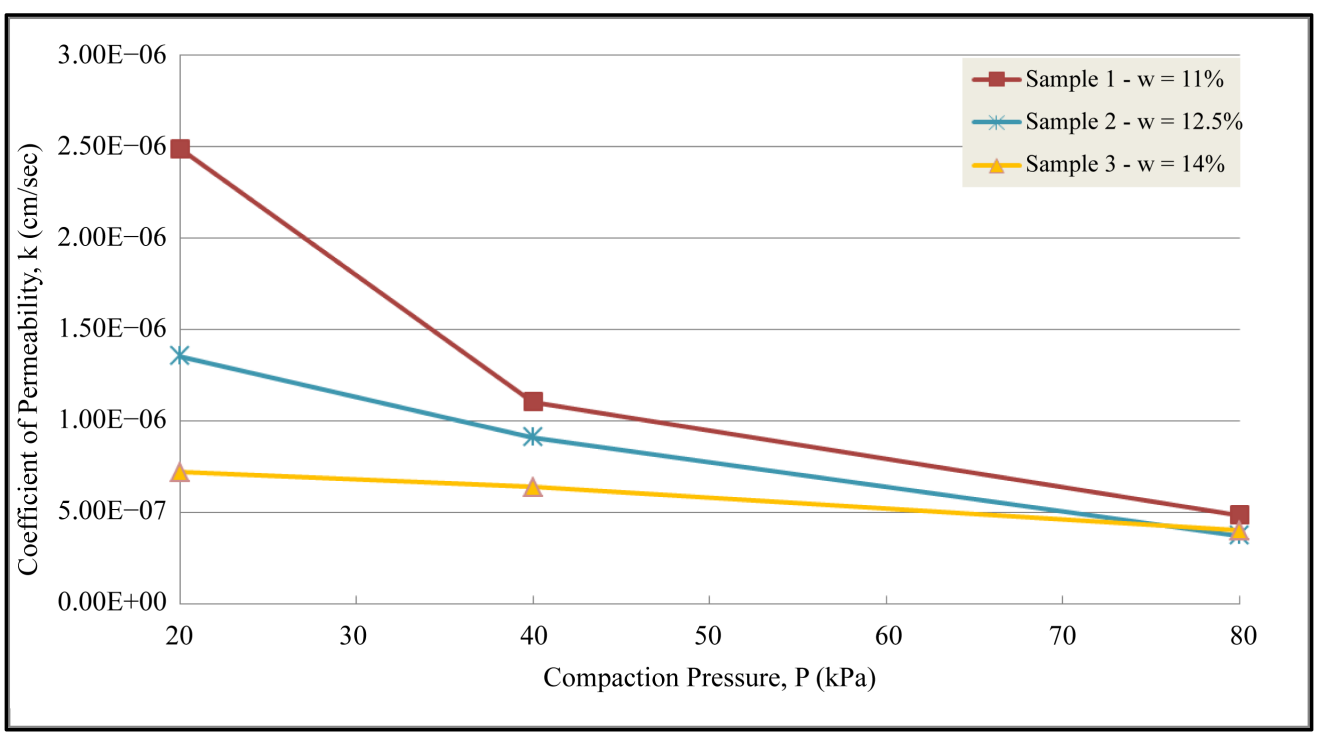

Figure 13. Relation between compaction pressure and coefficient of permeability.

biggest effect of compaction pressure was found at sample 3 which has the highest amount of water content. However, the coefficient of permeability converges on the same value after given more than $40 \mathrm{kPa}$ pressure. Therefore, a minimum of $40 \mathrm{kPa}$ pressure was needed to give a proper compaction to a various material contained in waste rock.

\subsection{Numerical Analysis for Effect of Compacted Layer}

After determining the amount of pressure needed to compact waste rock, the use of compacted layer from waste rock to improve the stability of out pit dumping area was studied. Firstly, laboratory test was carried out to obtain the physical and mechanical properties of compacted sample. The summary of its properties was given in Table 2.

As known from the previous investigation, the swamp material which is the base of failure out pit dumping was the cause of out pit dumping area instability. Therefore, constructing compacted layer above the swamp area by using waste rock was proposed to improve the stability of out pit dumping area in the future. To see the effect of this proposed method, numerical model for simulating the effect of compacted layer at the base of out pit dumping was constructed, as shown in Figure 14.

Various thickness of compacted layer which are $2 \mathrm{~m}, 4 \mathrm{~m}$, and $6 \mathrm{~m}$ was used in numerical model to see its effect to the out pit dumping area stability with $15 \mathrm{~m}$ thickness of swamp material. The result was shown on Figures 15-17. Further analysis was conducted by simulating both thickness of compacted layer and swamp material to obtain the ratio of compacted layer to swamp material as can be seen in Figure 18, Figure 19.

Based on result shown in Figures 15-17, both of shear failure and low strength factor zone are decrease with increasing thickness of compacted layer. The required thickness of compacted layer for $15 \mathrm{~m}$ thickness of swamp material was $6 \mathrm{~m}$. Moreover, result at Figure 17 indicates that another stage of waste rock dumping with height of 10 meter was able to be constructed with $6 \mathrm{~m}$ thickness of compacted layer at the base of out pit dumping area. Similar result was obtained for thickness of compacted material $2 \mathrm{~m}$ and $4 \mathrm{~m}$ and swamp material $5 \mathrm{~m}$ and $10 \mathrm{~m}$ respectively. The out pit dumping area was in stable condition from both simulations. Therefore, thickness ratio between swamp material and compacted layer to maintain the out pit dump stability is around 2.5.

\section{Conclusion}

Based on investigation, the cause of out pit dumping area failure near Pit East, Lati Area, PT Berau Coal was the existence of swamp material at the base of out pit dumping area. Improvement of out pit dumping area stability in order to prevent such failure occurs in the future is carried out by layering the swamp material with compacted waste rock before the waste rock dumping is constructed. An amount of minimum $40 \mathrm{kPa}$ pressure is needed to form compacted layer. Numerical model shows that the stability of out pit dumping area can be improved by 
Table 2. Physical and mechanical properties of compacted waste rock.

\begin{tabular}{ccc}
\hline Material Properties & Unit & Compacted Waste Rock \\
\hline Density & $\mathrm{MN} / \mathrm{m}^{3}$ & 0.01 \\
Young's modulus & $\mathrm{MPa}$ & 119 \\
Poisson ratio & & 0.4 \\
Shear strength & $\mathrm{MPa}$ & 0.13 \\
Internal friction angle & $\mathrm{Degree}$ & 31.2 \\
Cohesion & $\mathrm{MPa}$ & 0.144 \\
\hline
\end{tabular}

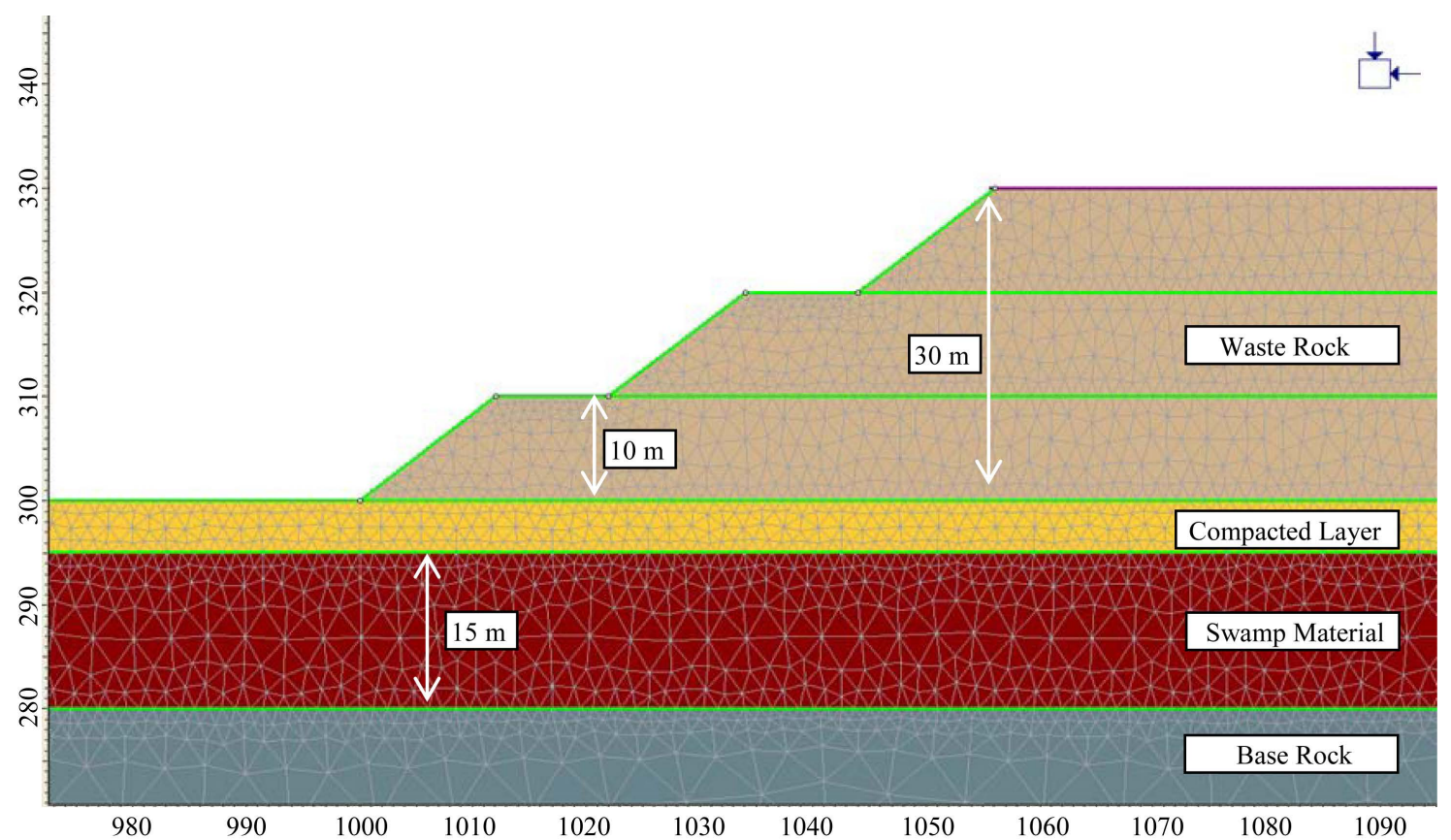

Figure 14. Numerical model with compacted layer.

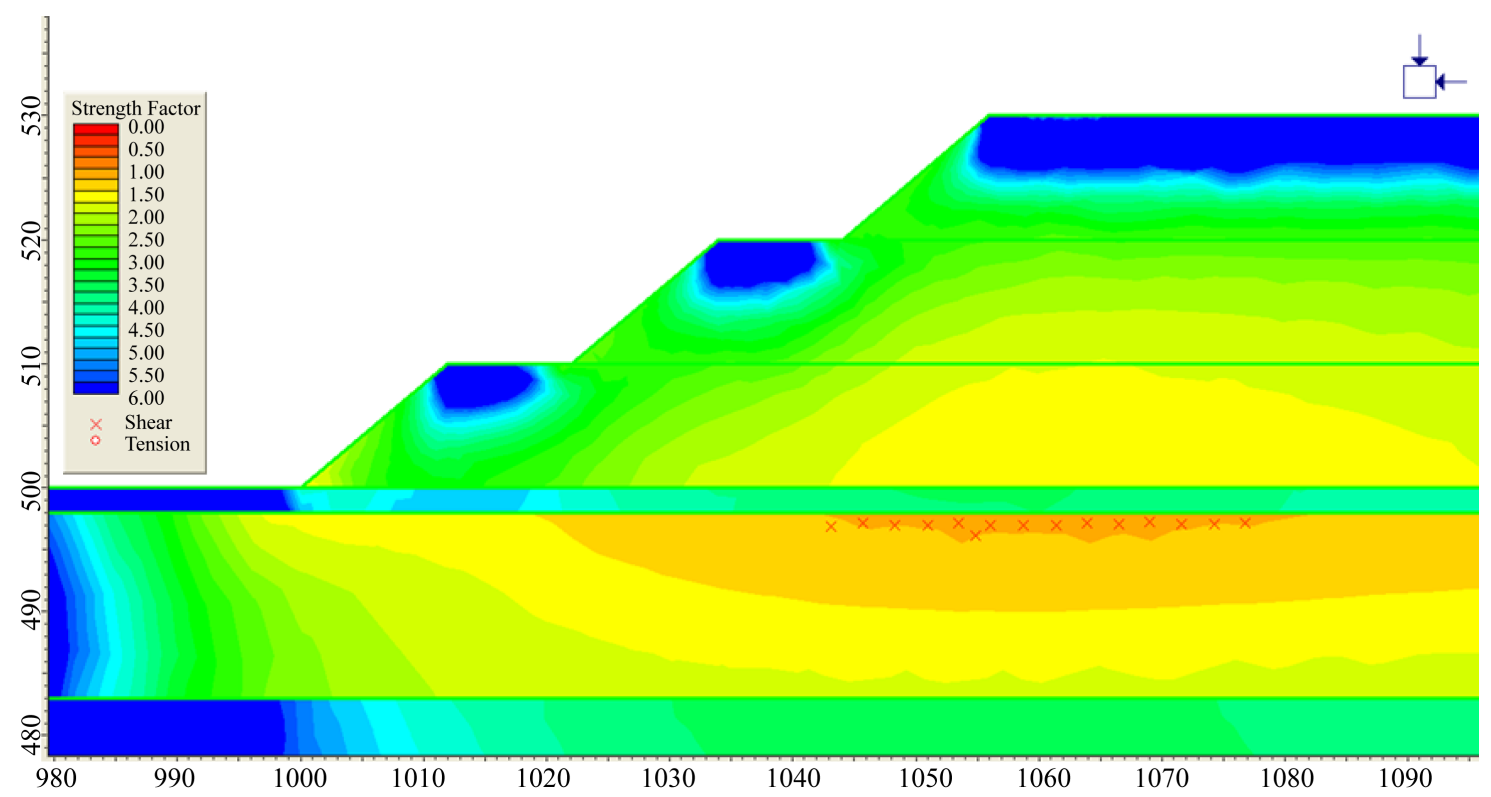

Figure 15. Numerical model with 2 m compacted layer. 


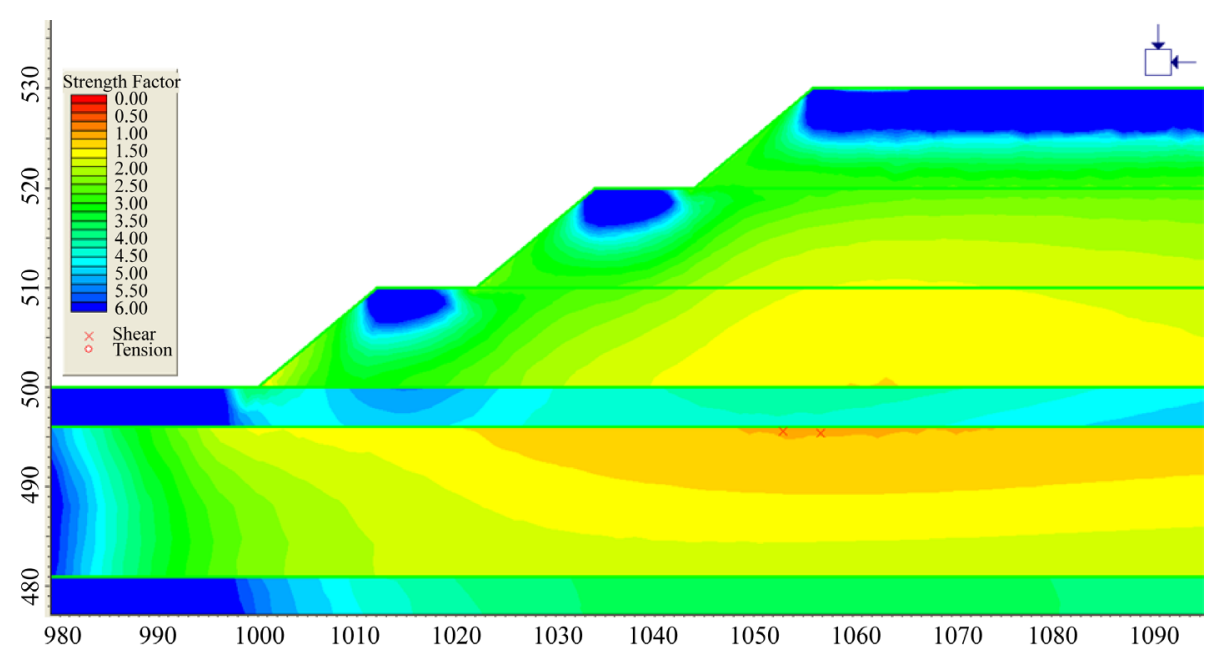

Figure 16. Numerical model with $4 \mathrm{~m}$ compacted layer.

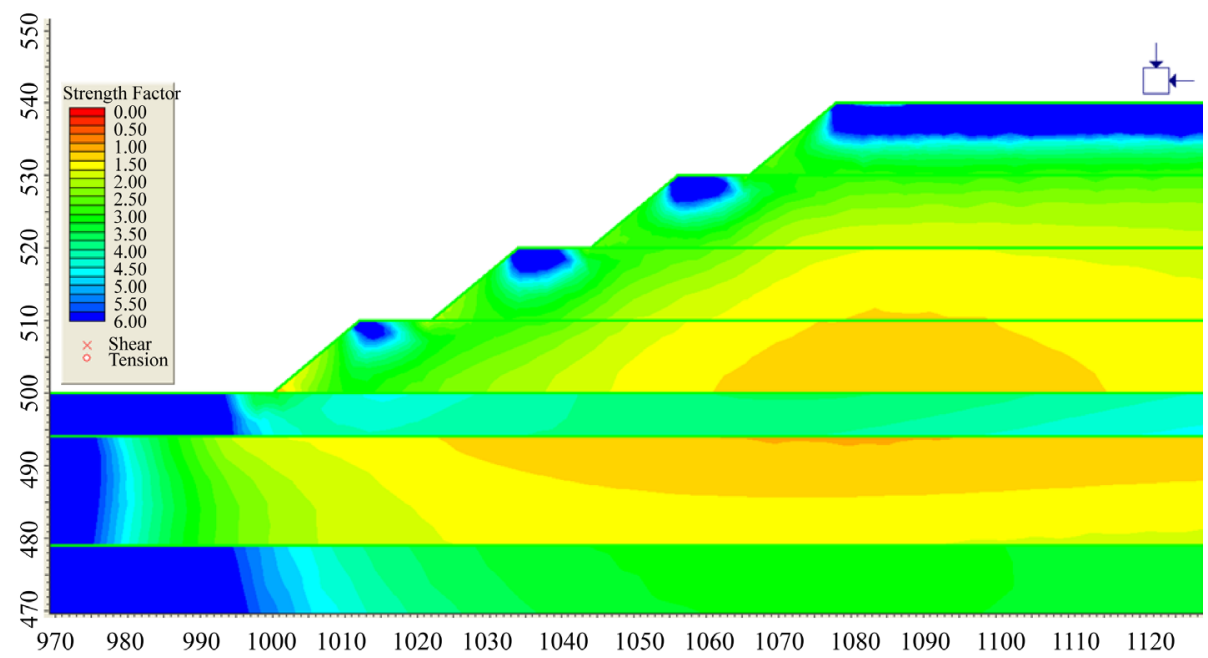

Figure 17. Numerical model with $6 \mathrm{~m}$ compacted layer.

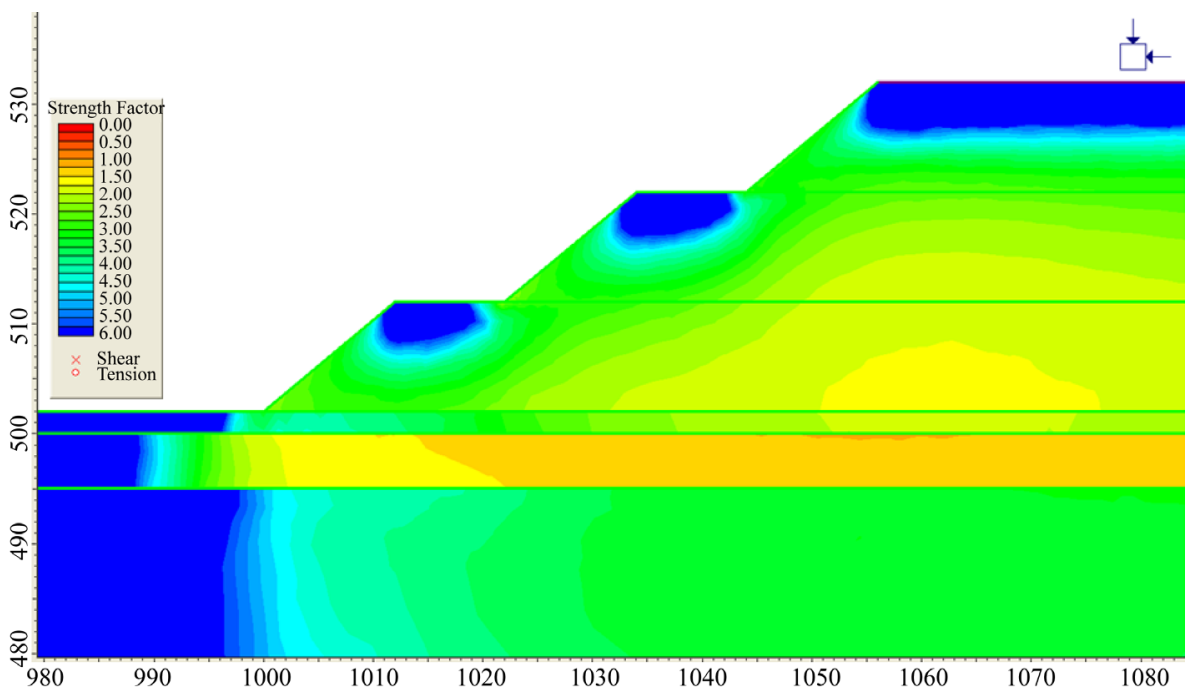

Figure 18. Numerical model with $2 \mathrm{~m}$ compacted layer and $5 \mathrm{~m}$ swamp material. 


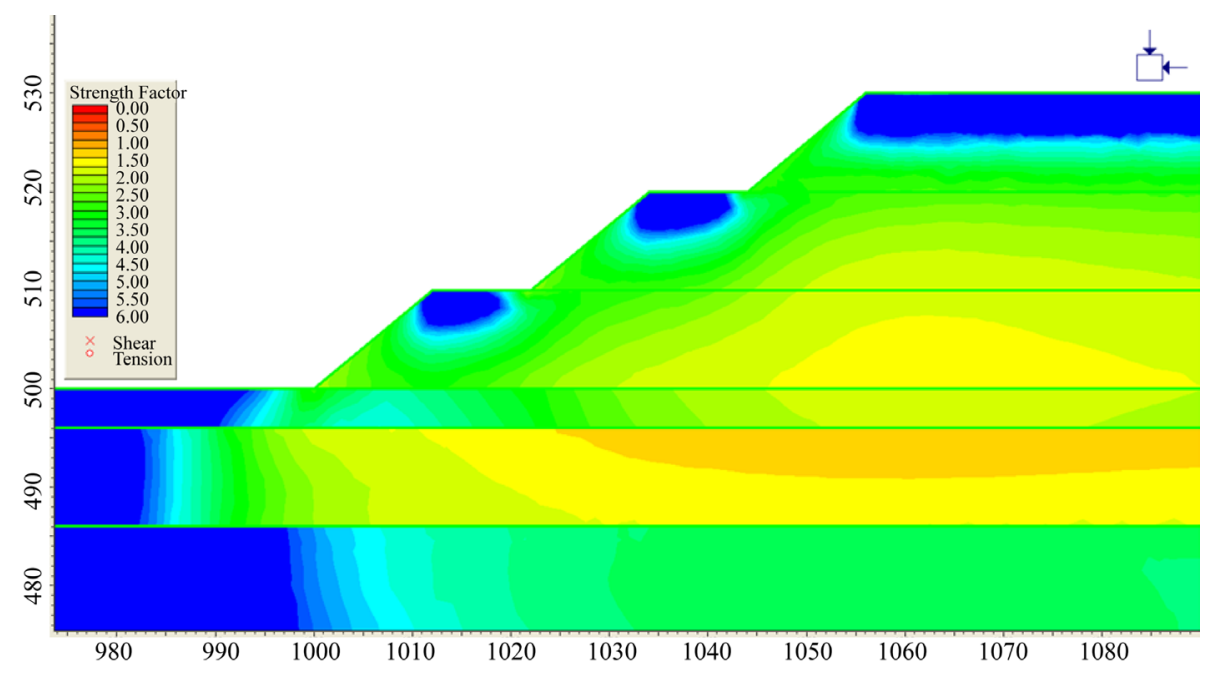

Figure 19. Numerical model with $4 \mathrm{~m}$ compacted layer and $10 \mathrm{~m}$ swamp material.

layering compacted layer above the swamp material. The thickness ratio between swamp material and compacted layer to maintain the out pit dump stability is around 2.5 .

\section{Acknowledgements}

Authors would like to acknowledge PT Berau Coal Management for the possibility and opportunity to conduct this study. Moreover, authors would like to acknowledge members of Rock Engineering and Mining Machinery Laboratory of Kyushu University for all support and discussion during conducting this research.

\section{References}

[1] Tosin, S. and Kadir, R. (1996) Type of Middle Miocene Sediment Reservoir in Tarakan Sub Basin, Tarakan BasinEast Kalimantan. Proceedings of the 25th Indonesian Geologist Association Conference, Jakarta, 9-11 December 1997, 495-512.

[2] Situmorang, R.L. and Burhan, G. (1995) Geological Map of the Tanjungredeb Quadrangle, Kalimantan, Scale 1:250,000. Report, Geological Research and Development Centre, Bandung.

[3] Hustrulid, W. and Kuchta, M. (2013) Open Pit Mine Planning and Design. 3th Edition, Taylor \& Francis Group, Boca Raton.

[4] Griffiths, D.V. and Lane, P.A. (1999) Slope Stability Analysis by Finite Elements. Geotechnique, 49, 387-403. http://dx.doi.org/10.1680/geot.1999.49.3.387

[5] Duncan, J.M. (1996) State of the Art: Limit Equilibrium and Finite-Element Analysis of Slopes. Journal of Geotechnical Engineering, 122, 577-596. http://dx.doi.org/10.1061/(ASCE)0733-9410(1996)122:7(577)

[6] The Japanese Geotechnical Society (2010) Geotechnical Handbook. The Japanese Geotechnical Society, Tokyo. 